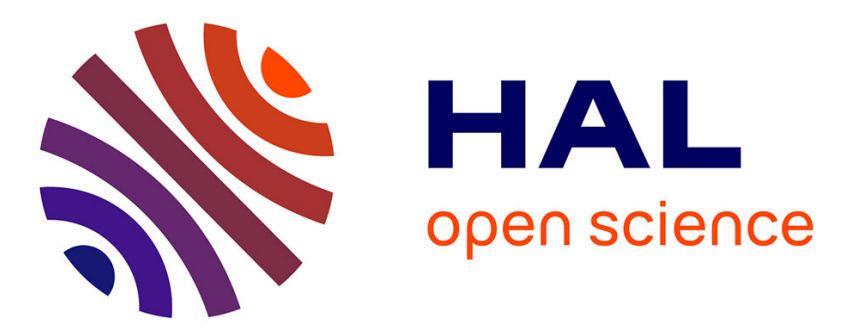

\title{
beta-Lactoglobulin as a Molecular Carrier of Linoleate: Characterization and Effects on Intestinal Epithelial Cells in Vitro
}

S. Le Maux, L. Giblin, Thomas Croguennec, Said Bouhallab, A. Brodkorb

\section{- To cite this version:}

S. Le Maux, L. Giblin, Thomas Croguennec, Said Bouhallab, A. Brodkorb. beta-Lactoglobulin as a Molecular Carrier of Linoleate: Characterization and Effects on Intestinal Epithelial Cells in Vitro. Journal of Agricultural and Food Chemistry, 2012, 60 (37), pp.9476-9483. 10.1021/jf3028396 . hal00849233

\section{HAL Id: hal-00849233}

\section{https://institut-agro-rennes-angers.hal.science/hal-00849233}

Submitted on 29 May 2020

HAL is a multi-disciplinary open access archive for the deposit and dissemination of scientific research documents, whether they are published or not. The documents may come from teaching and research institutions in France or abroad, or from public or private research centers.
L'archive ouverte pluridisciplinaire $\mathbf{H A L}$, est destinée au dépôt et à la diffusion de documents scientifiques de niveau recherche, publiés ou non, émanant des établissements d'enseignement et de recherche français ou étrangers, des laboratoires publics ou privés. 


\title{
$\beta$-Lactoglobulin as a Molecular Carrier of Linoleate: Characterization and Effects on Intestinal Epithelial Cells in Vitro
}

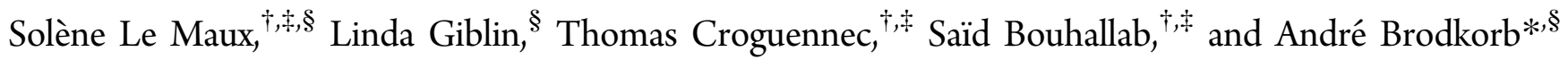 \\ ${ }^{\dagger}$ INRA, UMR1253 STLO, 65 rue de Saint Brieuc, F-35042 Rennes, France \\ ${ }^{\ddagger}$ AGROCAMPUS OUEST, UMR1253 STLO, 65 rue de Saint Brieuc, F-35042 Rennes, France

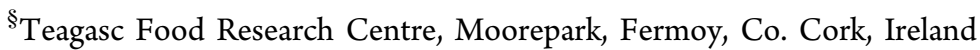

Supporting Information

ABSTRACT: The dairy protein $\beta$-lactoglobulin $(\beta \mathrm{lg})$ is known to bind hydrophobic ligands such as fatty acids. In the present work, we investigated the biological activity in vitro of linoleate once complexed to bovine $\beta$ lg. Binding of linoleate (C18:2) to

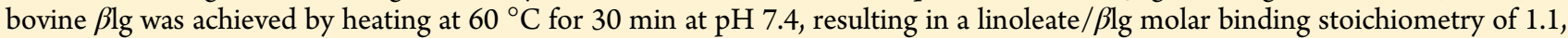
2.1, and 3.4. Two types of binding sites were determined by ITC titrations. Binding of linoleate induced the formation of covalent dimers and trimers of $\beta \mathrm{lg}$. The $\mathrm{LD}_{50}$ on Caco- 2 cells after $24 \mathrm{~h}$ was $58 \mu \mathrm{M}$ linoleate. However, cell viability was unaffected when $200 \mu \mathrm{M}$ linoleate was presented to the Caco- 2 cells as part of the $\beta \lg$ complex. The Caco- 2 cells did not increase mRNA transcript levels of long chain fatty acid transport genes, FATP4 and FABPpm, or increase levels of the cAMP signal, in response to the presence of $50 \mu \mathrm{M}$ linoleate alone or as part of the $\beta \lg$ complex. Therefore, it is proposed that $\beta \lg$ can act as a molecular carrier and alter the bioaccessibility of linoleate/linoleic acid.

KEYWORDS: $\beta$-lactoglobulin, sodium linoleate/linoleic acid, stoichiometry, Caco-2, cytotoxicity

\section{INTRODUCTION}

Linoleic acid (LA, cis,cis-9,12-octadecadienoic acid, n-6, 18:2) is an essential long-chain fatty acid (LCFA). World Health Organization (WHO) and Food and Agriculture Organization of the United Nations (FAO) recommend an adequate intake of LA of $2 \%$ of total energy. ${ }^{1} \mathrm{LA}$ is a precursor to long chain metabolites such as $\gamma$-linolenic acid, arachidonic acid, and eicosapentaenoic acid. ${ }^{2,3}$ Some of these polyunsaturated fatty acids such as LA or $\gamma$-linolenic acid have been shown to have anti-inflammatory properties. ${ }^{4}$ Replacement of saturated fat with LA is advised to improve serum lipoprotein profiles and reduce the risk of developing cardiovascular coronary artery disease. $^{5}$ LA is also cytotoxic at high concentrations to cancerous cells in vitro. ${ }^{6,7}$ LCFAs are taken up by intestinal epithelial cells by both active transport via specific fatty acid (FA) transporters and passive diffusion. ${ }^{8}$ However, uptake and bioavailability of fatty acids may be altered depending on the food matrix. 9,10

Bovine $\beta$-lactoglobulin $(\beta \lg )$ is the major whey protein in bovine milk but is absent in human milk. It is a globular protein with a monomeric molecular weight of $18.4 \mathrm{kDa}$, consisting of 162 amino acids. ${ }^{11}$ Despite intensive studies on biological, chemical, and physical properties of this protein, its biological function still remains unknown. ${ }^{11-14}$ Structurally, $\beta \lg$ belongs to the lipocalin family, ${ }^{15}$ of which most are able to bind small hydrophobic molecules, such as FA, hydrophobic vitamins, or curcumin. ${ }^{11-19} \beta \mathrm{lg}$ may be involved in transport, through the gastric tract, of hydrophobic substances naturally present in bovine milk, though clear evidence for this is lacking. ${ }^{13,14}$ All members of the lipocalin family contain a $\beta$-barrel, shaped into a flattened calyx, composed of eight antiparallel $\beta$-strands. It has been suggested that $\beta \lg$ binds hydrophobic ligands in its internal calyx. $^{20,21}$ The existence of binding sites in a crevice near the $\alpha$-helix on the external surface of the $\beta$-barrel has also been reported. ${ }^{11,22-26}$ However, the binding sites and stoichiometry of several ligands have been controversial. ${ }^{12,21,25}$

$\beta \lg$ and LA are derived from food sources, $\beta \lg$ from milk and LA from many edible oils and fats, such as safflower oil, grape seed oil, or corn oil and indeed milk fat. ${ }^{27-29}$ On a daily basis, people in the Western world consume significant quantities of both $\beta \lg$ and LA. Little information is known on the interaction between the water-soluble form of LA, linoleate, and $\beta \mathrm{lg}$. Indeed, how this interaction impacts protein structure and LA's biological properties is also not known. This study investigated the $\beta \mathrm{lg}$-linoleate complex formation in aqueous solution, the binding properties, and the effect on protein structure. To investigate the bioavailability of the FA in the formed complexes, compared to FA alone, cytotoxicity was measured on intestinal epithelial cells in vitro. The active transport of FA in the cells was studied by two different methods. Intracellular cyclic adenosine $3^{\prime}, 5^{\prime}$-monophosphate (cAMP) levels in viable Caco- 2 cells were measured in the presence of linoleate alone or within the $\beta \mathrm{lg}$-linoleate complex, as an indication of active FA transport using cAMP signal transduction. Messenger RNA transcript levels of the LCFA transporter genes, fatty acid binding protein (FABPpm) and fatty acid transport protein 4 (FATP4), in the presence of linoleate alone or within the $\beta \mathrm{lg}-$ linoleate complex were also measured.

Received: April 2, 2012

Revised: $\quad$ August 27, 2012

Accepted: August 27, 2012

Published: August 27, 2012 


\section{MATERIALS AND METHODS}

Materials. $\beta$-Lactoglobulin ( $96 \%$ purity) was obtained from Davisco Foods International, Inc. (Eden Prairie, Minnesota) and sodium linoleate (purity $\geq 98 \%$ ) from Sigma-Aldrich (St. Louis, MO). All other chemicals and solutions were purchased from Sigma-Aldrich unless stated otherwise.

Isothermal Titration Calorimetry (ITC). ITC was used to determine the interaction parameters between $\beta \lg$ and linoleate. ITC experiments were performed on a VP-ITC microcalorimeter (Microcal, Northampton MA). Solutions of $\beta \lg (0.163 \mathrm{mM})$ and linoleate $(9.64 \mathrm{mM})$ in phosphate buffered saline (PBS; $0.01 \mathrm{M}$ phosphate buffer, $2.7 \mathrm{mM} \mathrm{KCl}$, and $137 \mathrm{mM} \mathrm{NaCl}, \mathrm{pH} 7.4)$ were degassed under vacuum before titration experiments. Measurements were performed at $60{ }^{\circ} \mathrm{C}$. The reference cell was filled with PBS, and the sample cell $(1.425 \mathrm{~mL})$ was filled with $\beta \mathrm{lg}$ solution. $\beta \mathrm{lg}$ was titrated at $60{ }^{\circ} \mathrm{C}$ with 29 successive $10 \mu \mathrm{L}$ injections of linoleate. The injection time was $20 \mathrm{~s}$, and the time between injections was fixed at $600 \mathrm{~s}$ to allow thermodynamic equilibrium. During titrations, the solution in the sample cell was stirred at $310 \mathrm{rpm}$ to ensure complete mixing of the solution. The control measurement was obtained by titrating sodium linoleate into the buffer. The first injection peak was ignored for the analysis. Data were analyzed using MicroCal Origin, version 7.0, provided by the manufacturer: the integrated area of each peak was plotted versus the linoleate $/ \beta \mathrm{lg}$ molar ratio, providing binding constants.

Preparation of $\beta \mathbf{l g}$-Linoleate Complexes. The $\beta \mathrm{lg}$-linoleate complexes were prepared by heating a solution of $\beta \mathrm{lg}$ and sodium linoleate according to Lišková et al. ${ }^{30}$ with the following modifications. Briefly, $0.163 \mathrm{mM} \beta \mathrm{lg}$ was dissolved in phosphate buffered saline $(\mathrm{pH}$ 7.4), and sodium linoleate was added to reach final linoleate $/ \beta \mathrm{lg}$ molar ratios of $5,7.5$, and 10 . Solutions were heated for $30 \mathrm{~min}$ at $60{ }^{\circ} \mathrm{C}$, then immediately cooled on ice. Samples were extensively dialyzed against distilled water prior to freeze-drying. A control of sodium linoleate was dialyzed using the same conditions. No FA was detectable by gas chromatography in the control.

Determination of the FA Content by Gas Chromatography (GC). The FA content of the complexes was determined by GC following a protocol adapted from Palmquist and Jenkins. ${ }^{31}$ Briefly, the internal standard tridecanoic acid $(\mathrm{C} 13: 0)$ was added to $\sim 4 \mathrm{mg}$ of complexes. FA were converted to fatty acid methyl esters (FAME) by the addition of $1.5 \mathrm{~mL}$ of $10 \%$ methanolic $\mathrm{HCl}$ and $1 \mathrm{~mL}$ of hexane. The samples were vortexed and heated to $90{ }^{\circ} \mathrm{C}$ for $2 \mathrm{~h}$. After cooling on ice, $1 \mathrm{~mL}$ of hexane and $3 \mathrm{~mL}$ of $10 \% \mathrm{~K}_{2} \mathrm{CO}_{3}$ were added, and the samples were vortexed. After phase separation, the heptane phase (upper phase) containing the FAME was analyzed as previously described by Coakley et al., ${ }^{32}$ using a CP-SELECT CB column for FAME $(100 \mathrm{~m}, 0.25 \mathrm{~mm}, 0.25 \mu \mathrm{m}$ film thickness, Varian BV, Middelburg, The Netherlands), a Varian 3400 GLC (Varian, Walnut Creek, CA), and a flame ionization detector.

Gel Permeation HPLC (GP-HPLC). The concentration of monomers and aggregates were determined by GP-HPLC using a TSK G SW guard column $(7.5 \times 7.5 \mathrm{~mm}$, Tosoh Bioscience $\mathrm{GmbH}$, Stuttgart, Germany) and a TSK G2000 SW column $(7.5 \times 600 \mathrm{~mm}$, Tosoh Bioscience $\mathrm{GmbH}$ ) connected to an HPLC system, consisting of a Waters 2695 Separations Module, a Waters 2487 Dual $\lambda$ Absorbance Detector, and an Empower Pro software (Waters, Milford, MA) to acquire and analyze data. Then, $0.05 \mathrm{mg}$ of protein was injected using a solution of $30 \%$ acetonitrile (LabScan Analytical Sciences, Dublin, Ireland) (v/v) and $0.1 \%(\mathrm{w} / \mathrm{v})$ trifluoracetic acid in Milli-Q water (Millipore, Carrigtwohill, Ireland) as an eluent, at a flow rate of $0.5 \mathrm{~mL} / \mathrm{min}$. The use of acetonitrile ensured that native $\beta$ lg was eluted in monomeric form. The method was calibrated using a set of protein molecular-weight standards (Sigma-Aldrich).

The proportions of monomers (including native and unfolded) of $\beta \mathrm{lg}$ were deduced from GP-HPLC data by integration of the peaks area. The proportion of $\beta \mathrm{lg}$ oligomers in samples was calculated by subtraction of the concentration of monomer from the initial protein concentration, determined by HPLC.
Polyacrylamide Gel Electrophoresis. Samples were analyzed by sodium dodecyl sulfate-polyacrylamide gel electrophoresis (SDSPAGE) in order to determine the nature of the oligomer interaction. Mini-Protean TGX precast Gels (4-20\% resolving gel, Bio-Rad Laboratories Inc., Hercules, CA) were used on a Mini Protean II system (Bio-Rad) according to the manufacturer's instructions. Samples were prepared under reducing (with $\beta$-mercaptoethanol) and nonreducing conditions. Protein was visualized by staining with Coomassie blue (Bio-Safe Coomassie Stain G-250, Bio-Rad). An Amersham Low Molecular Weight Calibration kit (14.4 to $97 \mathrm{~kg} / \mathrm{mol}$, GE Healthcare UK Limited, UK) was used as the molecular weight standard.

Cell Culture. The Caco- 2 cell line was purchased from the European Collection of Cell Cultures (collection reference: ECACC 86010202) and was derived from human colonic adenocarcinoma cells. When fully differentiated, Caco- 2 cells can mimic the enterocytes of the intestine.

Cells cultures were maintained in a humidified $37{ }^{\circ} \mathrm{C}$ incubator with a $5 \% \mathrm{CO}_{2}$ in air atmosphere. Cells were routinely grown in $75 \mathrm{~cm}^{2}$ plastic flasks in Dulbecco's modified Eagle's medium (DMEM) containing $4.5 \mathrm{~g} / \mathrm{L}$ glucose and $0.584 \mathrm{~g} / \mathrm{L}$ L-glutamine. Media for subculture was supplemented with $10 \%(\mathrm{v} / \mathrm{v})$ fetal bovine serum (FBS), $100 \mathrm{U} / \mathrm{mL}$ penicillin, and $100 \mathrm{mg} / \mathrm{mL}$ streptomycin. At $80 \%$ confluency, cells were trypsinated with $0.25 \%$ trypsin/EDTA, diluted 1:6 in media, and reseeded. Media were changed three times a week. All cells used in these studies were between passage number 25 and 40 .

Cytotoxicity Assay. Cytotoxicity of test samples on Caco-2 cell proliferation was determined by the MTS assay, using CellTiter 96 Aqueous One Solution Cell Proliferation Assay according to the manufacturer's intructions (Promega Corporation, Madison, Wisconsin). Briefly, Caco- 2 cells were seeded in $96-$ well plates, at a cell density of $2 \times 10^{4}$ cells/well, using serum-free media (DMEM only supplemented with $100 \mathrm{U} / \mathrm{mL}$ penicillin and $100 \mathrm{mg} / \mathrm{mL}$ streptomycin). After $24 \mathrm{~h}$, cells were treated with different concentrations of linoleate $(0$ to $150 \mu \mathrm{M}), \beta \lg (0$ to $150 \mu \mathrm{M})$, or linoleate $/ \beta \lg$ complexes (complex with a molar ratio of 1,2 , and 3 , which contained 0 to $150 \mu \mathrm{M}$ linoleate) in serum-free media for $24 \mathrm{~h}$. The One Solution Cell Proliferation reagent $(20 \mu \mathrm{L})$ was then added to each well for a further $3 \mathrm{~h}$. Viability was defined as the ratio of absorbance of treated cells to untreated cells (cells exposed to serumfree Media only) at $490 \mathrm{~nm}$. Each cell exposure was repeated six times, and intraplate variation was accounted for by repeating the exposures on 3 different days $(n=18)$. The lethal dose $50\left(\mathrm{LD}_{50}\right)$ values were determined using Graph-Pad Prism software 3.03 (GraphPad Software Inc., La Jolla CA). The sigmoidal dose-response with variable slope was used to fit the measured curves and calculate $\mathrm{LD}_{50}$.

Real-Time Cell Analyzer (RTCA). Cell growth was monitored in real time using the Real Time Cell Analyzer (RTCA) SP Instrument and the xCELLigence system (Roche Diagnostic Limited, West Sussex, UK). The RTCA system measures the impedance of the bottom of the well, which is a function of cell number and cell morphology. As the cell numbers increase, the impedance increases. Correspondingly, if the cell morphology changes (cells swell or shrink), the impedance will also be affected. The RTCA software generates a cell index value based on the level of impedance. Caco-2 cells in serum-free media were seeded in 16 E-Plates (Roche Diagnostic Limited) at a cell density of $1 \times 10^{4}$ cells/well. After $24 \mathrm{~h}$ in a humidified $37^{\circ} \mathrm{C}$ incubator with a $5 \% \mathrm{CO}_{2}$ in air atmosphere, cells were treated for $48 \mathrm{~h}$ with different concentration of linoleate $(0$ to $100 \mu \mathrm{M}), \beta \lg (0$ to $100 \mu \mathrm{M})$, or linoleate $-\beta \lg$ complexes (molar ratio of 3 linoleate $/ \beta \lg$ containing 0 to $100 \mu \mathrm{M}$ linoleate) in serum-free media. Data were analyzed using the RTCA software 1.2 (Roche Diagnostic): the cell index was plotted versus time, and effective concentration $50\left(\mathrm{EC}_{50}\right)$ was determined by regression analysis of the cell index data versus the concentration of the compound after $48 \mathrm{~h}$. Using the software, the time dependent $\mathrm{EC}_{50}$ curves were determined by calculating the $\mathrm{EC}_{50}$ values at 20 time points within $48 \mathrm{~h}$, and these $\mathrm{EC}_{50}$ values were plotted versus time.

Cyclic AMP Assay. A cAMP assay based on homogeneous timeresolved fluorescence, the cAMP HiRange kit (Cisbio Bioassays, Codolet, France), was performed according to the manufacturer's 
instructions. Caco-2 cells were seeded into 96-well-half area plates (Cruinn Diagnostics, Ireland) at a density of $1 \times 10^{5}$ cells/well in serum-free media. After an overnight incubation in a humidified $37^{\circ} \mathrm{C}$ incubator with $5 \% \mathrm{CO}_{2}$ in air atmosphere, media were aspirated, $25 \mu \mathrm{L}$ of serum-free media/IBMX (3-isobutyl-1-methylxanthine) was then added to all wells, and the plate was preincubated for $30 \mathrm{~min}$ at $37^{\circ} \mathrm{C}$ and $5 \% \mathrm{CO}_{2}$. Cells were incubated with $25 \mu \mathrm{L}$ of linoleate $(0$ to 50 $\mu \mathrm{M}), \beta \lg (0$ to $50 \mu \mathrm{M})$, or linoleate $-\beta \lg$ complexes (molar ratio of 3 linoleate $/ \beta \lg$ containing 0 to $50 \mu \mathrm{M}$ linoleate) at room temperature for $30 \mathrm{~min}$ with gentle shaking. Forskolin $(25 \mu \mathrm{L}$ of $1 \mu \mathrm{M})$ was used as a positive control. Accumulation of the intracellular cAMP was measured using the cAMP HiRange kit following the manufacturer's instructions. Fluorescence was read using a FLUOstar Omega multimode microplate reader and analyzed with the FLUOstar Omega software (BMG LABTECH GmbH, Ortenberg, Germany). Intracellular levels of cAMP (in the $\mathrm{nM}$ range) were determined by interpolating fluorescence readings from a cAMP standard curve generated in the same assay.

Messenger RNA Levels of FABPpm and FATP4. For quantifying FABPpm and FATP4 mRNA levels, real time PCR (RT-PCR) was performed in a LightCycler 480 instrument (Roche Diagnostic Limited) based on the principles of absolute quantification.

Caco- 2 cells in serum-free media were seeded in 6-well plates at a density of $5.7 \times 10^{5}$ cells/well overnight in a humidified $37{ }^{\circ} \mathrm{C}$ incubator with $5 \% \mathrm{CO}_{2}$ in air atmosphere. Cells were then exposed to linoleate $(0$ to $50 \mu \mathrm{M})$ or linoleate- $\beta \lg$ complexes (molar ratio of 3 linoleate $/ \beta \lg$ containing 0 to $50 \mu \mathrm{M}$ linoleate) for $4 \mathrm{~h}$ in serum-free media. A control was done with $\beta \lg (0$ to $50 \mu \mathrm{M})$. The supernatant was removed, and total RNA was extracted from the cells using the QIAGEN miRNeasy Mini kit (QIAGEN Limited, West Sussex, UK). Quality and quantity of total RNA were measured by glyoxyl gel electrophoresis and spectrophotometrically using the NanoDrop 1000 (Thermo Fisher Scientific, Wilmington NC). First strand cDNA was generated from $1 \mu \mathrm{g}$ of total RNA using the Bioline cDNA synthesis kit (Bioline, London, UK).

All primers were designed across intron/exon boundaries and synthesized by Eurofins MWG Operon (Ebersberg, Germany). Primers for human FABPpm were designed using DNAstar Lasergene 8 software (DNAstar, Madison WI, USA) and based on the GenBank sequence (accession number NM002080). FABPpm forward primer sequence was 5'-CCGGAACAGTGGAAGGAAATAGC-3', and the reverse primer sequence was $5^{\prime}$-TTGAGGGGAGGGTTGGAATACAT-3'. The annealing temperature for amplification was $57^{\circ} \mathrm{C}$. The forward primer sequence used for human FATP4 was $5^{\prime}$ CAGGGCGCCAACAACAAGAAGATT- $3^{\prime}$, and the reverse primer sequence was 5'-GCAAAGCGCTCCAGGTCACAGT-3', both designed from the accession number NM002080. The annealing temperature for amplification was $58{ }^{\circ} \mathrm{C}$.

Plasmid standards for FABPpm and FATP4 were created by cloning an amplified PCR product into the pCR4-TOPO vector using the TOPO-TA cloning system (Invitrogen, Life Technologies, Carlsbad CA) according to the manufacturer's instructions. The cloned amplicon was (a) identified by PCR amplification, using gene specific primer pairs and/or digestion of plasmid DNA using the EcoRI restriction enzyme and (b) confirmed by sequencing (Beckman Coulter Genomics, Essex, UK). For RT-PCR standards, plasmid DNA was linearized and quantified using the Nanodrop 1000. Standard curve preparation involved creating a series of dilutions from $10^{9}$ to $10^{2}$ copies $/ \mu \mathrm{L}$.

For each $10 \mu \mathrm{L}$ Lightcycler reaction, $1 \mu \mathrm{L}$ of test cDNA or serially diluted standard was used. The LightCycler 480 SYBR Green I Master kit (Roche Diagnostics Limited) was used for quantification according to the manufacturer's instructions using $0.5 \mu \mathrm{M}$ of both the forward and reverse primers. All cDNA samples were tested in duplicate. Data were analyzed using the LightCycler 480 Software (Roche Diagnostic Limited).

Statistical Analysis. Results were compared using Minitab 15 statistical Software (Minitab Limited, Coventry, UK) and the ANOVA system with a Fisher's least significant difference comparison. Experiments were performed at least in triplicate.

\section{RESULTS}

Linoleate $/ \beta \lg$ complexes were produced at $60{ }^{\circ} \mathrm{C}$. The heating condition was below the denaturation temperature of $\beta \mathrm{lg}$ $\left(\sim 70{ }^{\circ} \mathrm{C}\right.$ at neutral $\left.\mathrm{pH}\right)$, in a temperature range where $\beta \mathrm{lg}$ is in the R-state. ${ }^{33,34} \beta \lg$ R-state is characterized by small changes in $\beta \lg$ tertiary structure, a slight expansion in its volume, and an increase in accessible surface area compared to native $\beta$ lg. ${ }^{35}$ The salt of LA was used because it is fully soluble in water up to its critical micelle concentration (CMC: $2 \mathrm{mM}^{36}$ ). Using the water-soluble form of LA permits direct contact between $\beta \mathrm{lg}$ and linoleate allowing complex formation while avoiding the use of ethanolic solutions to solubilize the FA. ${ }^{37}$

Interaction between Linoleate and $\beta$ lg. The thermodynamic parameters of linoleate binding to $\beta \mathrm{lg}$ were investigated by ITC. The changes in the enthalpy during the binding of $\beta \mathrm{lg}$ titrated with a solution of sodium linoleate was investigated at $\mathrm{pH} 7.4$ and at $60^{\circ} \mathrm{C}$. The heat exchange from the interaction of $\beta \lg$ with linoleate is shown in Figure 1. Each peak represents the heat exchange within the system after an injection and indicates that linoleate-binding to $\beta \lg$ is an exothermic process. Figure 1B depicts peak integration corrected by control (titration of sodium linoleate in buffer). The energy released during the titration decreased as the molar ratio increased. The curve leveled off at a linoleate $/ \beta$ lg ratio of $\sim 3$. The saturation point of $\beta \lg$ by linoleate was above a molar ratio of 13 . For linoleate $/ \beta \lg$ molar ratios of 3 to 13 , the released heat did not plateau. Instead the heat decreased by $1.5 \mathrm{kcal} / \mathrm{mol}$ of linoleate. The binding titration curve was best fitted according to a two

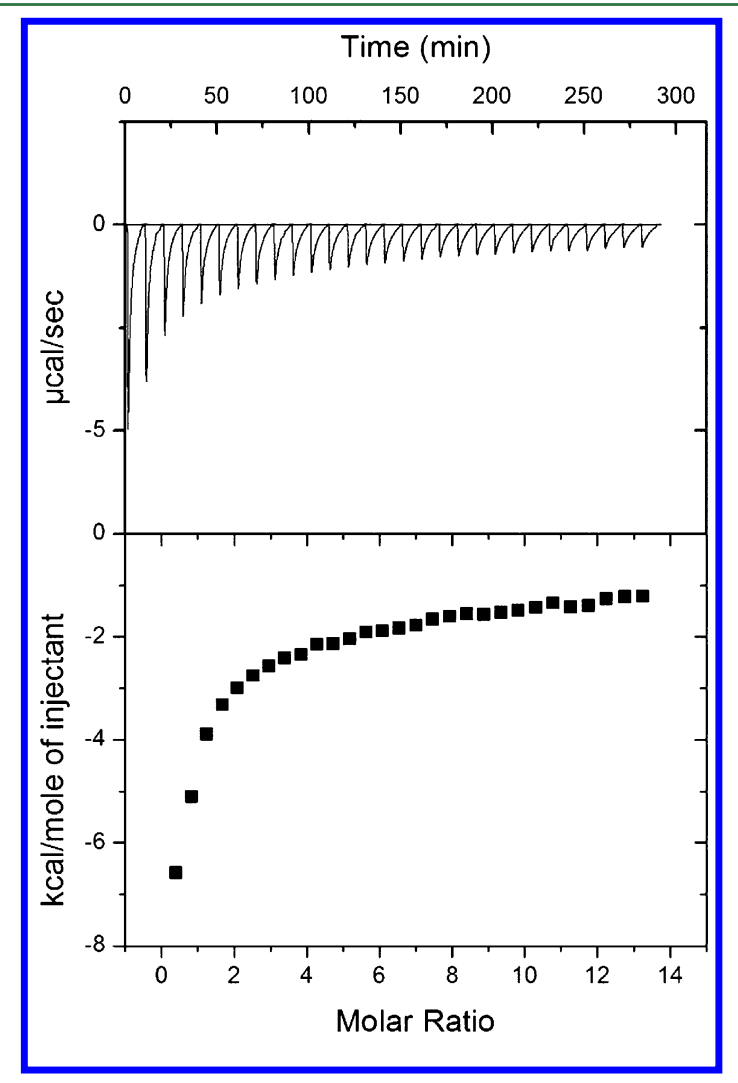

Figure 1. Microcalorimetric titration of $\beta \mathrm{lg}$ with linoleate in PBS buffer $(\mathrm{pH} 7.4)$ at $60^{\circ} \mathrm{C}$. (A) raw heat signal for the titration of $\beta \mathrm{lg}$ $(0.16 \mathrm{mM})$ with $10 \mu \mathrm{L}$ increments of $9.64 \mathrm{mM}$ linoleate. (B) Area under each peak integrated and plotted against the linoleate $/ \beta \lg$ molar ratio. 
set of binding sites model, which yielded the thermodynamic constants for the two sites: $K_{\mathrm{a} 1}=(2.70 \pm 2.03) \times 10^{5} \mathrm{M}^{-1}, n_{1}=$ $0.62 \pm 0.004 ; K_{\mathrm{a} 2}=(5.91 \pm 3.85) \times 10^{3} \mathrm{M}^{-1}, n_{2}=5.75 \pm 0.51$, where $K_{\mathrm{a}}$ is the association constant and $\mathrm{n}$ the stoichiometry. The return to thermodynamic equilibrium was very slow (>1500 s). A longer equilibrium time did not affect the results (data not shown). The slow return to thermodynamic equilibrium could be due to the occurrence of other structural events, i.e., the formation of oligomers (see below). No heat change was observed during the direct injection of sodium linoleate in buffer solution (control sample).

$\beta \mathrm{lg}$-Linoleate Complex Formation: Stoichiometry and Oligomerization of the Protein. $\beta \mathrm{lg}$-Linoleate complexes were prepared by heating $0.16 \mathrm{mM} \beta \mathrm{lg}$ at $60{ }^{\circ} \mathrm{C}$ for $30 \mathrm{~min}$ at $\mathrm{pH} 7.4$ in the presence of 5, 7.5, and $10 \mathrm{~mol}$ equiv of linoleate. To remove excess of unbound FA, samples were extensively dialyzed prior to freeze-drying.

Final stoichiometry of linoleate $/ \beta \lg$ was determined from freeze-dried complexes using GC. A comparison of molar ratios of linoleate $/ \beta \lg$ before the reaction, after dialysis and freezedrying, is shown in Figure 2A. The amount of linoleate bound to $\beta \mathrm{lg}$ increased by increasing the initial ratio of linoleate $/ \beta \mathrm{lg}$. For an initial linoleate $/ \beta \lg$ molar ratio of $5,7.5$, and 10 , the amount of linoleate bound to one protein after dialysis was $1.05 \pm 0.10,2.14 \pm 0.06$, and $3.35 \pm 0.47 \mathrm{~mol}$, respectively. Consequently, complexes with a linoleate $/ \beta \lg$ molar ratio of 1 , 2 , and 3 were formed.

As shown by GP-HPLC analysis (Figure $2 \mathrm{~B}$ and $\mathrm{C}$ ), the presence of linoleate induced oligomerization of the protein. The amount of oligomers increased significantly with the molar ratios of linoleate $/ \beta \mathrm{lg}$. In the absence of linoleate (control), the amount of oligomers in $\beta$ lg samples was $12 \%$. In the presence of linoleate ( 3 linoleate $/ \beta \mathrm{lg}$ ), the amount of oligomers reached up to $45 \%$ of total protein concentration. The oligomers were mainly dimers and trimers of $\beta \mathrm{lg}$ as shown in Figure $2 \mathrm{C}$ and confirmed by the SDS-PAGE experiment (see below). However, no significant change in the protein secondary structures was associated with oligomer formation, as indicated by FTIR (data not shown).

These results were confirmed by SDS-PAGE. Under nonreducing conditions, the SDS-PAGE analysis of native $\beta \lg$ and heated $\beta \lg \left(\right.$ at $60{ }^{\circ} \mathrm{C}$ ) (Figure 2C) showed a major band corresponding to the $\beta \lg$ monomer with small amount of dimers and trimers. In the presence of linoleate, the intensity of the bands corresponding to $\beta \lg$ dimers and trimers intensified. Under reducing conditions, no difference was observed between native $\beta \lg$, heated $\beta \lg$, and linoleate $/ \beta \lg$ complexes with a molar ratio of 1,2 , and 3 linoleate $/ \beta \lg$ (Figure $2 \mathrm{C}$ ). This indicated that dimers and trimers were covalently bound by disulfide links.

Cytotoxicity on Caco-2 Cells. To elucidate the effect of $\beta \mathrm{lg} /$ linoleate on human epithelial cell viability, the human colonic adenocarcinoma cells, Caco-2, were exposed to $\beta \mathrm{lg}$, linoleate or complexes for $24 \mathrm{~h}$ (Figure $3 \mathrm{~A}$ ). $\mathrm{LD}_{50}$, the concentration required to decrease the cell viability by $50 \%$, was then calculated. $\beta \mathrm{lg}$ was not toxic to Caco- 2 cells at the concentrations tested ( 0 to $150 \mu \mathrm{M}$ ), as measured by the MTS assay. In contrast, the $\mathrm{LD}_{50}$ of linoleate was $58.04 \pm 4.21 \mu \mathrm{M}$. Linoleate $/ \beta \lg$ complexes, where the corresponding linoleate concentration varied from 0 to $150 \mu \mathrm{M}$, had no cytotoxic effect on Caco- 2 cells after $24 \mathrm{~h}$ of incubation.

Toxic effects of $\beta \mathrm{lg}$, linoleate, or complexes in real time over $48 \mathrm{~h}$ were studied using RTCA (Figure 3B). The cell index,

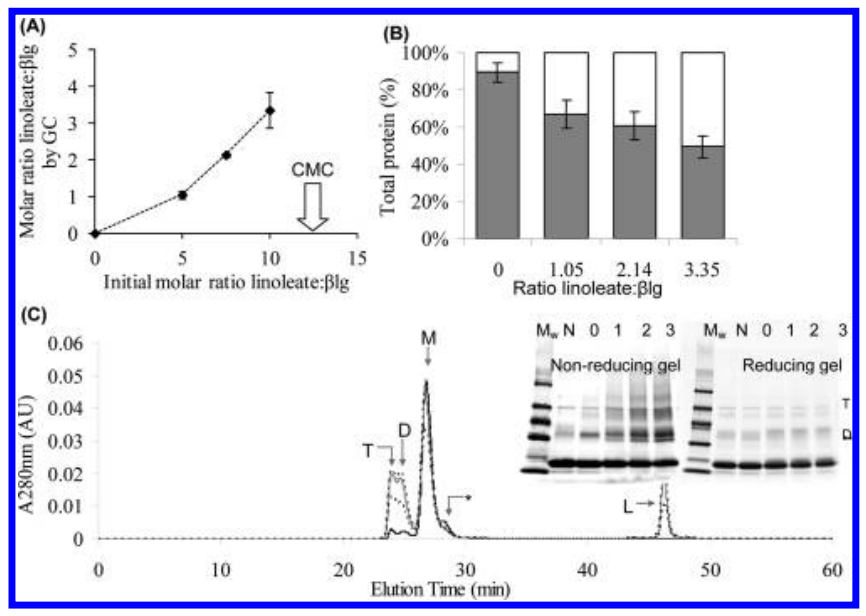

Figure 2. $\beta \mathrm{lg}$-linoleate complex formations: $0.16 \mathrm{mM} \beta$-lactoglobulin in the absence or presence of linoleate were heat treated at $60{ }^{\circ} \mathrm{C}$ for $30 \mathrm{~min}$, extensively dialyzed and freeze-dried. (A) Correlation of the molar ratios of linoleate $/ \beta \mathrm{lg}$ added to the starting solutions with the molar ratios of linoleate $/ \beta \lg$ that were detected by GC analysis in the $\beta \mathrm{lg} /$ linoleate samples after extensive dialysis and freeze-drying. The arrow represents the CMC of the sodium linoleate. ${ }^{36}$ Complexes with a linoleate $/ \beta \lg$ molar ratio of $1.05 \pm 0.10,2.14 \pm 0.06$, and $3.35 \pm 0.47$ mol were formed, referred to as complexes with a linoleate $/ \beta$ lg molar ratio of 1,2 , and 3. (B) Protein composition observed by GP-HPLC (shown in C). The molar ratio of linoleate/ $\beta$ lg in dialyzed solutions is indicated on the $x$-axis, the total protein content on the $y$-axis as follows: gray area, monomers; white area, oligomers. (C) Composition of solutions of $\beta \mathrm{lg}$ in the presence or absence of linoleate observed by GP-HPLC chromatograms (30\% acetonitrile and 0.1\% TFA). Black line, $\beta \lg$ heated without sLA; dotted black line, complex of 1 linoleate/ $\beta$ lg molar ratio; light gray line, complex of 2 linoleate $/ \beta$ lg molar ratio; dotted gray line, complex of 3 linoleate/ $\beta$ lg molar ratio. The inserts show the SDS-PAGE profile of $\beta \mathrm{lg}$-linoleate complexes under nonreducing (left gel) and reducing (right gel) conditions. $M_{\mathrm{w}}$, molecular weight markers $(14.4,20.1,30,45,66$, and $97 \mathrm{kDa}) ; \mathrm{N}$, native $\beta \lg ; 0, \beta \lg$ control treated to complex formation conditions; lane 1,2 and 3, complex with a final molar ratio of 1,2 , and 3 linoleate $/ \beta \mathrm{lg}$, respectively. T, $\beta \lg$ trimer; $\mathrm{D}, \beta \lg$ dimer; $\mathrm{M}, \beta \lg$ monomer; $*, \alpha$ la monomer; L, linoleate. A band with slightly lower molecular weight than $\beta \lg$ dimers was observed in the presence of linoleate under nonreducing conditions $(* *)$. This maybe due to the formation of heterodimers of $\beta \lg$ and $\alpha \mathrm{la}$, as the electrophoretic band corresponding to $\alpha$ la monomers decreased in the presence of linoleate.

which is a function of the impedance at the bottom of the well, was measured. The cell index relates to cell viability and/or cell morphology. Results showed a decrease of the cell index by 1.95 when the concentration of $\beta \mathrm{lg}$ increased from 0 to 100 $\mu \mathrm{M}$, compared to the control cells without compound. However, the parallel MTS assay showed no change in cell viability (Figure 3A). Taken together, this allowed the authors to conclude that $\beta \mathrm{lg}$ alters cell morphology rather than cell viability. Interestingly, at the low concentrations of 5,10 , and $25 \mu \mathrm{M}$ linoleate, an increase of cell index was observed for linoleate alone compared to the control (Figure 3B, linoleate). At concentrations of 50,75 , and $100 \mu \mathrm{M}$, the linoleate cell index decreased by 2.54 (for $100 \mu \mathrm{M}$ linoleate) compared to that of the control. However, the response of Caco- 2 cells to $\beta \mathrm{lg}$-linoleate complexes differed from that of linoleate alone at equivalent molar concentrations. A decrease in cell index was observed after $3 \mathrm{~h}$ of exposure to $100 \mu \mathrm{M}$ linoleate, whereas the 3 linoleate $/ \beta \lg$ complex $(100 \mu \mathrm{M}$ linoleate) required $12.5 \mathrm{~h}$ exposure to decrease the cell index (cf. arrows on Figures 3B, 
linoleate and cplx). $\beta \mathrm{lg}$-Linoleate complexes containing 5, 10, 25 , and $50 \mu \mathrm{M}$ linoleate increased the Caco- 2 cell index after $48 \mathrm{~h}$. $\beta \mathrm{lg}$-Linoleate complexes containing $100 \mu \mathrm{M}$ linoleate in the complex decreased the cell index by 0.49 after $48 \mathrm{~h} . \mathrm{EC}_{50}$, the concentration required to obtain $50 \%$ of the maximum effect, was calculated at different time points. After $48 \mathrm{~h}, \mathrm{EC}_{50}$

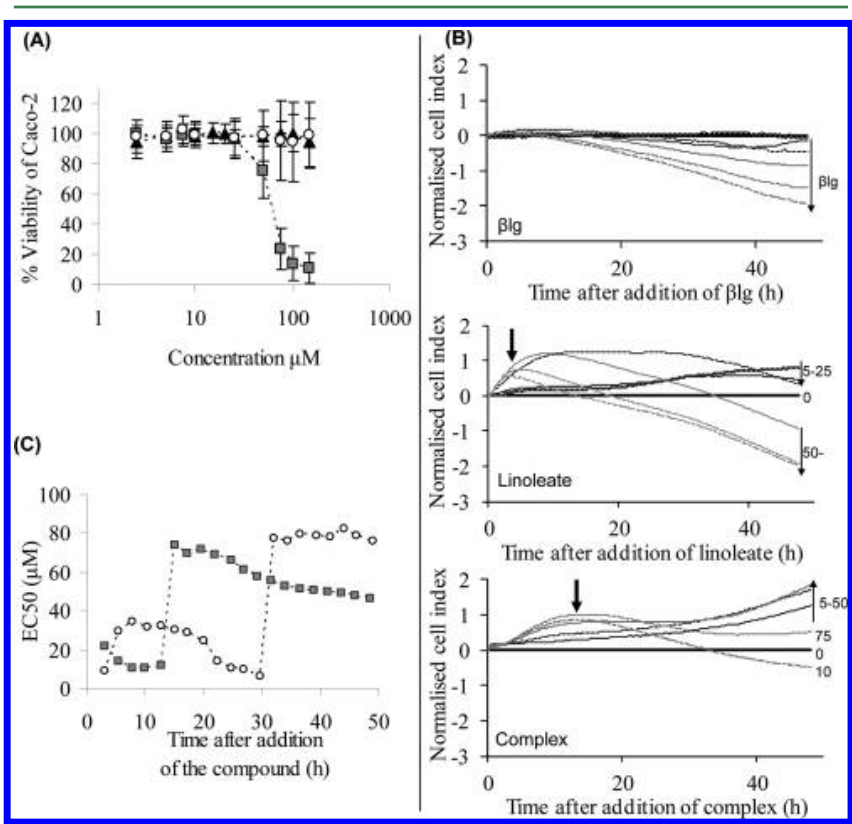

Figure 3. Cytotoxicity of $\beta \mathrm{lg}$, linoleate, and $\beta \mathrm{lg}$-linoleate complexes on Caco-2 cells. Cytotoxicity activity was assessed using the (A) MTS assay and (B,C) RTCA system. (A) \% viability after $24 \mathrm{~h}$ on $2 \times 10^{4}$ Caco-2 cells compared to control cells. $\beta$ lg concentration, filled triangle with dashed lines; linoleate concentration, gray box with dashed lines; and linoleate concentration in the $\beta \mathrm{lg}$-linoleate complexes, diamond with dashed lines are given on the $x$-axis ( 0 to $150 \mu \mathrm{M}$ ). (B) Normalized cell index (difference between the cell index and the cell index without compound) over time in hours. $1 \times 10^{4}$ Caco-2 cells were exposed to $0 \mu \mathrm{M}$, thick solid line; $5 \mu \mathrm{M}$, wavy line; $10 \mu \mathrm{M}$, solid line; $25 \mu \mathrm{M}$, dashed line; $50 \mu \mathrm{M}$, thin solid line; $75 \mu \mathrm{M}$, dashed line; $100 \mu \mathrm{M}$, long dashed line of $\beta \lg (\mathrm{B}-\beta \mathrm{lg}$ ), linoleate (Blinoleate), and linoleate in the 3 linoleate- $\beta \lg$ complex (B-complex). The large arrows on B-linoleate and B-complex indicate the start of the normalized cell index decrease for the highest concentration. (C) Time dependence $\mathrm{EC}_{50}$ is based on panel $\mathrm{B} ; \mathrm{EC}_{50}$ is calculated over a $48 \mathrm{~h}$ exposure to linoleate (gray box with dashed line) or the 3 linoleate $-\beta \lg$ complex (diamond with dashed line). was $35 \mu \mathrm{M}$ for linoleate alone and $98 \mu \mathrm{M}$ when linoleate was part of a 3 linoleate $/ \beta \lg$ complex. A time dependent $\mathrm{EC}_{50}$ was calculated to indicate $\mathrm{EC}_{50}$ changes as a function of time (Figure $3 \mathrm{C}$ ). At $13 \mathrm{~h}$, the $\mathrm{EC}_{50}$ was reached with $74 \mu \mathrm{M}$ linoleate alone. In contrast, it took $30 \mathrm{~h}$ for the $\mathrm{EC}_{50}$ to reach $78 \mu \mathrm{M}$ linoleate when 3 linoleate was complexed to $\beta \mathrm{lg}$.

Cellular Response to $\beta$ lg, Linoleate, and $\beta$ lgLinoleate Complexes. Cyclic AMP is a ubiquitous intercellular/intracellular messenger, which may be involved in active FA uptake by cells. ${ }^{38}$ Cyclic AMP levels were measured in Caco-2 cells exposed to linoleate, $\beta \mathrm{lg}$, or complexes at nontoxic concentrations (50 $\mu \mathrm{M}$ linoleate). No changes were detected in cAMP levels by incubation with linoleate ( 0 to 50 $\mu \mathrm{M}), \beta \lg (0$ to $50 \mu \mathrm{M})$, or linoleate $-\beta \lg$ complexes (0 to 50 $\mu \mathrm{M}$ linoleate) as measured by a FRET-based time-resolved fluorescence assay. Messenger RNA transcript levels of the FA transporter genes, FATP4 and FABPpm, in Caco-2 cells were investigated as an indication of active transport of linoleate across the cell membrane. Messenger RNA levels of FATP4 and FABPpm were not significantly increased in Caco-2 cells after 4 $\mathrm{h}$ of incubation with linoleate $(0$ to $50 \mu \mathrm{M})$ or linoleate $-\beta \mathrm{lg}$ complexes with a concentration of 0 to $50 \mu \mathrm{M}$ linoleate (Figure 1, Supporting Information).

\section{DISCUSSION}

$\beta \lg$ and linoleate formed complexes that protected Caco- 2 cells from the cytotoxic effects of linoleate (Figure 3). Intracellular cAMP levels (Figure 4) and mRNA FATP4 and FABPpm levels were unaffected by the presence of linoleate either alone or in a protein complex. SDS-PAGE and HPLC analysis of the complexes revealed the formation of intermolecular disulfide bonds between protein molecules, which increased with higher molar ratios of linoleate $/ \beta \mathrm{lg}$ (Figure $2 \mathrm{~B}$ and $\mathrm{C}$ ). These observations, combined with those from ITC (Figure 1), allowed us to suggest a binding mechanism between $\beta \lg$ and linoleate that modifies the cytotoxic effect of the FA.

Linoleate interacted with $\beta \lg$ via two different binding sites with respective affinity constants of $2.7 \times 10^{5}$ and $5.9 \times$ $10^{3} \mathrm{M}^{-1}$. These association constants are similar to those reported for other hydrophobic ligands. ${ }^{39,40}$ Spector and Fletcher ${ }^{40}$ reported two binding sites with an association constant in the order of $10^{5} \mathrm{M}^{-1}$ and $10^{3} \mathrm{M}^{-1}$ for the binding of $\beta \mathrm{lg}$ to palmitate, oleate, stearate, and laurate. Concomitant to linoleate binding, we also observed the formation of covalent protein oligomers, i.e., dimers and trimers, that could explain the stoichiometry value $(n=0.62)$ determined from ITC

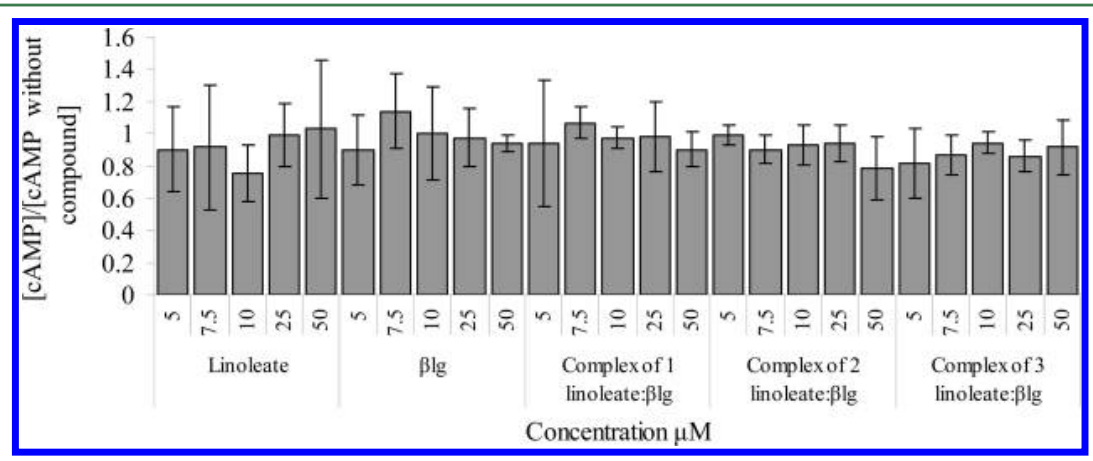

Figure 4. Relative intracellular cAMP levels in $1 \times 10^{5}$ Caco- 2 cells treated with different concentrations of linoleate, $\beta \mathrm{lg}$, and $\beta \mathrm{lg}-\mathrm{linoleate}$ complexes. cAMP without compound is defined as cAMP levels in Caco-2 cultured in medium without compound. No significant difference between samples and concentrations were found. 
experiments. This value could result from a mixture of complexes such as $(\beta \lg )_{2}$ (linoleate) $(n=0.5)$ and $(\beta \lg )_{3}(\text { linoleate })_{2}(n=0.67)$. This hypothesis is consistent with the simple shape of the ITC peaks, with slow return to equilibrium attributed to the induced oligomerization step. Recently, a crystallographic structure of the native $\beta \mathrm{lg} /$ linoleate complex, showing the fatty acid located at the protein calyx (stoichiometry $=1$ ), was published. ${ }^{41}$ Our results suggest that heating of the $\beta \mathrm{lg}$ and linoleate mixture may lead to the formation of other types of complexes.

$\beta \lg$ has a weak aptitude to aggregation below the temperature of denaturation. ${ }^{42}$ At $60{ }^{\circ} \mathrm{C}$, the presence of linoleate increased the formation of disulfide-linked dimers and trimers without the formation of larger aggregates. This work confirms previous work in our laboratory ${ }^{30}$ where the binding of sodium oleate to $\beta \mathrm{lg}$ at $60{ }^{\circ} \mathrm{C}$ decreased monomeric $\beta \mathrm{lg}$ and increased the formation of dimers and trimers. Protein aggregation in the presence of lipids has also been reported for other protein systems. ${ }^{43} \beta$ lg oligomerization into covalent dimers and trimers may be triggered by slight structural changes induced by linoleate binding to $\beta \mathrm{lg}$ monomers, as suggested by previous studies. 44,45

From the presented results, we propose a hypothetic binding mechanism where the interaction of the FA with the protein and the oligomerization of $\beta \lg$ take place in a single step: (1) At $60{ }^{\circ} \mathrm{C}$, native $\beta \mathrm{lg}$ monomers reversibly unfold to form nonnative R-state monomers. ${ }^{33}$ (2) Negatively charged linoleate molecules interact with positively charged regions at the surface of $\beta \mathrm{lg}$ monomers, as suggested from the exothermic signal of ITC experiments. Consequently, the formation of a linoleate/ $\beta \lg$ complex would favor additional hydrophobic interactions between proteins. (3) Two or three $\beta \lg$ molecules were then noncovalently cross-linked by one or two linoleate molecules bound to a high affinity binding site; this favors the formation of $\beta \lg$ oligomers by intermolecular disulfide bonds, making the unfolding irreversible after cooling.

This assumption is in agreement with the single peak structure showing a slow return to the thermodynamic equilibrium of ITC results. It probably indicates that several physicochemical phenomena can contribute simultaneously to the measured signal including (i) binding of linoleate to $\beta \mathrm{lg}$, (ii) conformational changes of $\beta \mathrm{lg}$ following the binding of linoleate molecules, (iii) oligomerization of the protein $\beta \mathrm{lg}$, and (iv) counterion release.

The protection provided by $\beta \mathrm{lg} /$ linoleate complexes to Caco2 cells from linoleate differs from that provided by the $\beta \mathrm{lg} /$ conjugated linoleic acid (CLA) complex. Although the different CLA isomers display varying effects on biological functions, ${ }^{46,47}$ a $2.46 c 9, t 11-C L A / \beta$ lg molar ratio complex resulted in a $30 \%$ increase in cytotoxicity after $48 \mathrm{~h}$ of exposure to c9,t11-CLA at a concentration of $100 \mu \mathrm{M}$, compared to that by $c 9, t 11-\mathrm{CLA}$ alone. ${ }^{17}$ HAMLET/BAMLET (Human/Bovine Alpha-lactalbumin Made LEthal to Tumor cells), a complex formed of oleic acid (OA) and $\alpha$-lactalbumin $(\alpha \mathrm{la})$, is more cytotoxic than OA on its own. ${ }^{48} \mathrm{OA}$ and LA by themselves exhibit cytotoxic effects on various cell lines. ${ }^{48,49}$ However, binding these FA to proteins such as $\beta \mathrm{lg}$, modify their cytotoxic effect compared to the FA on its own. Indeed, the $\mathrm{OA} / \alpha$ la complex is $\sim 40 \%$ more cytotoxic to human larynx carcinoma cells than free OA. ${ }^{48}$ However, recent studies based on the direct measurement of $\mathrm{OA}$ content in the incubation mixture would argue that $\mathrm{OA}$ alone or that involved in a complex have comparable cytotoxicity effects on various cells, with the protein alone having no effect. ${ }^{30,50}$ Frapin et al. ${ }^{39}$ showed that the structural constraints imposed by the double bonds of FA only weakly affects the interaction of FA with $\beta \mathrm{lg}$. The reduced cytotoxic effect observed with linoleate $/ \beta \lg$ complexes may relate to the solubility of the FA. OA has poor solubility in aqueous solution; its CMC is between 20 and $69 \mu \mathrm{M}$ at $\mathrm{pH} 8.3$ at the temperature and salt concentration tested by Knyazeva et al. ${ }^{48}$ Therefore, in the absence of protein, the amount of OA available to the cells would be low. The binding of OA to $\beta \mathrm{lg}$ or other proteins such as $\alpha$ la (HAMLET, BAMLET) increased the solubility of OA (Kehoe, J. J., personal communication) and possibly its bioavailability. The solubility of FA increases with the number of $\mathrm{C}=\mathrm{C}$ double bonds in the aliphatic chain. ${ }^{51}$ Consequently, the solubility of LA (C18:2) is higher than that of OA (C18:1). Under the experimental conditions used by Collin et al., ${ }^{36}$ sodium linoleate has a CMC of $2 \mathrm{mM}$. Hence, the binding of linoleate to $\beta \mathrm{lg}$ is unlikely to alter solubility but potentially alters linoleate uptake by altering levels of free FA.

The cytotoxicity of linoleate was concentration dependent, in agreement with that observed with $\mathrm{LA}^{7}$ Norman et al. ${ }^{52}$ showed that sodium linoleate was more cytotoxic to the epithelial mouse cells, Ehrlich ascite tumor, than emulisified LA. This effect may be explained by the higher solubility of sodium linoleate in aqueous bioassays with greater access to the Caco-2 cells. Prior to uptake, LCFA enters a low $\mathrm{pH}$ microclimate at the enterocyte surface. As this local $\mathrm{pH}$ is below their $\mathrm{p} K_{\mathrm{a}}$, protonation of LCFA will occur with LCFA entering in the FA form rather than the salt form. ${ }^{53}$ To date, it is not well understood how intestinal cells metabolize LA. A previous study showed that the FA cytotoxic effect was initiated by the mitochondrial apoptotic pathway with cytochrome $C$ release, indicating that uptake of LA is essential for its cytotoxic effect. ${ }^{6}$ FA cytotoxicity may also occur by an alteration of the cellular n-6 to n-3 polyunsaturated FA ratio adversely affecting membrane permeability and fluidity. ${ }^{8}$

LCFA are hydrophobic, and therefore, uptake by enterocytes was thought to occur by diffusion. However, recent studies suggest the involvement of protein-transfer mechanisms, with transport of LCFA reaching saturation at high concentrations in Caco-2 cells. ${ }^{8,38,54}$ It is likely that an efficient LCFA uptake by cells requires both passive and facilitated transfer, possibly using a cAMP pathway. ${ }^{38}$ However, in our study, no change in intracellullar cAMP levels was observed by viable intestinal cells exposed to different concentrations of linoleate and $\beta \mathrm{lg}-$ linoleate complexes ( 0 to $50 \mu \mathrm{M}$ linoleate). Nevertheless, the requirement of cAMP in facilitated LCFA uptake or metabolism is controversial and appears to depend on the FA and cell type used. Bovine oocytes treated with $100 \mu \mathrm{M}$ LA for 6 or $24 \mathrm{~h}$ decreased intracellular cAMP levels. ${ }^{55}$ A perfusion of $1 \mathrm{mmol} / \mathrm{L}$ plasma of eicosapentaenoic acid (EPA; C20:5 n-3) during $150 \mathrm{~min}$ decreased the cAMP level by $0.27 \mathrm{nmol} / \mathrm{g}$ tumor on MCF-7 human breast cancer xenografts perfused in situ in nude rats. ${ }^{56}$ In contrast, C6 glioma cells incubated with $100 \mu \mathrm{M}$ EPA for $48 \mathrm{~h}$ increased cAMP levels by $\sim 250 \% .{ }^{57}$ The FA transporters, FABPpm and FAPT4 have been involved in the uptake of LCFA by intestinal cells. ${ }^{54,58}$ Messenger RNA transcript levels of FATP4 and FABPpm were not increased upon exposure to linoleate, which suggests that either (a) there are sufficient quantities of FATP4 and FABPpm transporter proteins to transport linoleate or (b) these transporters are not involved in linoleate transport, at the concentrations tested. ${ }^{39}$

This study has demonstrated that $\beta \lg$ can bind at least three linoleate per $\beta \lg$ monomer at two different sets of binding sites. 
According to cell proliferation assays, linoleate can inhibit the viability of Caco- 2 cells, but $\beta \mathrm{lg}$-linoleate complexes appear to protect cells from the cytotoxicity effect of linoleate. This effect could be due to the relatively high solubility of linoleate. Caco-2 exposure to linoleate or $\beta \mathrm{lg}$-linoleate complexes did not modify intracellular cAMP levels or mRNA transcript levels of the LCFA transporter genes, FABPpm and FAPT4.

\section{ASSOCIATED CONTENT}

\section{S Supporting Information}

Levels of FABPpm and FATP4 mRNA transcripts in Caco-2 cells after $4 \mathrm{~h}$ exposure to linoleate. This material is available free of charge via the Internet at http://pubs.acs.org.

\section{AUTHOR INFORMATION}

\section{Corresponding Author}

*Telephone: +353 2542 222. Fax: +353 2542 340. E-mail: Andre.Brodkorb@teagasc.ie.

\section{Notes}

The authors declare no competing financial interest.

S.L.M. is currently supported by a Teagasc Walsh Fellowship and the Department of Agriculture, Fisheries and Food (FIRM project 08/RD/TMFRC/650). We also acknowledge funding from IRCSET-Ulysses Travel Grant.

\section{ACKNOWLEDGMENTS}

We express our gratitude to Alan Hennessy for the GC analysis.

\section{ABBREVIATIONS USED}

$\alpha$ la, $\alpha$-lactalbumin; $\beta$ lg, $\beta$-lactoglobulin; cAMP, cyclic adenosine 3',5'-monophosphate; CLA, conjugated linoleic acid; CMC, critical micelle concentration; DMEM, Dulbecco's modified Eagle's medium; $\mathrm{EC}_{50}$, effective concentration 50; FA, fatty acids; FABPpm, fatty acid binding protein; FAME, fatty acid methyl ester; FATP4, fatty acid transport protein 4; FBS, fetal bovine serum; GC, gas chromatography; GP-HPLC, gel permeation high performance liquid chromatography; HAMLET/BAMLET, human/bovine $\alpha$-lactalbumin made lethal to tumor cells; ITC, isothermal titration calorimetry; $K_{a}$, association constant; LA, linoleic acid; LCFA, long chain fatty acid; $\mathrm{LD}_{50}$, lethal dose 50; $n$, reaction stoichiometry; OA, oleic acid; RTCA, real time cell analyzer; RT-PCR, real time polymerase chain reaction

\section{REFERENCES}

(1) FAO/WHO. Joint Expert Consultation: Interim Summary of Conclusions and Dietary Recommendations on Total Fat \& Fatty Acids; WHO: Geneva, Switzerland, 2008.

(2) Mantzioris, E.; James, M. J.; Gibson, R. A.; Cleland, L. G. Differences exist in the relationships between dietary linoleic and alpha-linoleic acids and their respective long-chain metabolites. Am. J. Clin. Nutr. 1995, 61, 320-324.

(3) Russo, G. L. Dietary n-6 and n-3 polyunsaturated fatty acids: from biochemistry to clinical implications in cardiovascular prevention. Biochem. Pharmacol. 2009, 77, 937-946.

(4) Zhao, G.; Etherton, T. D.; Martin, K. R.; Vanden Heuvel, J. P.; Gillies, P. J.; West, S. G.; Kris-Etherton, P. M. Anti-inflammatory effects of polyunsaturated fatty acids in THP-1 cells. Biochem. Biophys. Res. Commun. 2005, 336, 909-917.

(5) Zock, P. L.; Katan, M. B. Linoleic acid intake and cancer risk: a review and meta-analysis. Am. J. Clin. Nutr. 1998, 68, 142-153.

(6) Lu, X.; Yu, H.; Ma, Q.; Shen, S.; Das, U. N. Linoleic acid suppresses colorectal cancer cell growth by inducing oxidant stress and mitochondrial dysfunction. Lipids Health Dis. 2010, 9, 106.
(7) Lu, X. F.; He, G. Q.; Yu, H. N.; Ma, Q.; Shen, S. R.; Das, U. N. Colorectal cancer cell growth inhibition by linoleic acid is related to fatty acid composition changes. J. Zhejiang Univ-SCI. B 2010, 11, 923930.

(8) Trotter, P.; Ho, S. Y.; Storch, J. Fatty acid uptake by Caco-2 human intestinal cells. J. Lipid Res. 1996, 37, 336.

(9) $\mathrm{Mu}, \mathrm{H}$. Bioavailability of omega-3 long-chain polyunsaturated fatty acids from foods. Agro Food Ind. Hi-Tech 2008, 19, 24-26.

(10) Singh, H.; Ye, A.; Horne, D. Structuring food emulsions in the gastrointestinal tract to modify lipid digestion. Prog. Lipid Res. 2009, $48,92-100$.

(11) Kontopidis, G.; Holt, C.; Sawyer, L. Invited review: betalactoglobulin: binding properties, structure, and function. J. Dairy Sci. 2004, 87, 785-796.

(12) Kontopidis, G.; Holt, C.; Sawyer, L. The ligand-binding site of bovine beta-lactoglobulin: evidence for a function? J. Mol. Biol. 2002, 318, 1043-1055.

(13) Perez, M. D.; Calvo, M. Interaction of beta-lactoglobulin with retinol and fatty acids and its role as a possible biological function for this protein: a review. J. Dairy Sci. 1995, 78, 978-988.

(14) Ragona, L.; Zetta, L.; Fogolari, F.; Molinari, H.; Pérez, D. M.; Puyol, P.; Kruif, K. D.; Löhr, F.; Rüterjans, H. Bovine betalactoglobulin: interaction studies with palmitic acid. Protein Sci. 2000, 9, 1347-1356.

(15) Flower, D. R. The lipocalin protein family: structure and function. Biochem. J. 1996, 318, 1.

(16) Considine, T.; Patel, H. A.; Singh, H.; Creamer, L. K. Influence of binding conjugated linoleic acid and myristic acid on the heat-and high-pressure-induced unfolding and aggregation of beta-lactoglobulin B. Food Chem. 2007, 102, 1270-1280.

(17) Jiang, H. R.; Liu, N. Self-assembled beta-lactoglobulinconjugated linoleic acid complex for colon cancer-targeted substance. J. Dairy Sci. 2010, 93, 3931-3939.

(18) Wang, Q.; Allen, J. C.; Swaisgood, H. E. Binding of vitamin D and cholesterol to beta-lactoglobulin. J. Dairy Sci. 1997, 80, 10541059.

(19) Sneharani, A. H.; Karakkat, J. V.; Singh, S. A.; Rao, A. G. A. Interaction of curcumin with beta-lactoglobulin-stability, spectroscopic analysis, and molecular modeling of the complex. J. Agric. Food Chem. 2010, 58, 11130-11139.

(20) Forrest, S. A.; Yada, R. Y.; Rousseau, D. Interactions of vitamin D3 with bovine beta-lactoglobulin A and beta-casein. J. Agric. Food Chem. 2005, 53, 8003-8009.

(21) Wu, S. Y.; Pérez, M. D.; Puyol, P.; Sawyer, L. Beta-lactoglobulin binds palmitate within its central cavity. J. Biol. Chem. 1999, 274, 170.

(22) Dong, S. Y.; Zhao, Z. W.; Ma, H. M. Characterization of local polarity and hydrophobic binding sites of beta-lactoglobulin by using N-terminal specific fluorescence labeling. J. Proteome Res. 2006, 5, 2631

(23) Lange, D. C.; Kothari, R.; Patel, R. C.; Patel, S. C. Retinol and retinoic acid bind to a surface cleft in bovine beta-lactoglobulin: a method of binding site determination using fluorescence resonance energy transfer. Biophys. Chem. 1998, 74, 45-51.

(24) Muresan, S.; van der Bent, A.; de Wolf, F. A. Interaction of betalactoglobulin with small hydrophobic ligands as monitored by fluorometry and equilibrium dialysis: Nonlinear quenching effects related to protein-protein association. J. Agric. Food Chem. 2001, 49, 2609-2618.

(25) Wang, Q. W. Q.; Allen, J. C.; Swaisgood, H. E. Protein concentration dependence of palmitate binding to beta-lactoglobulin. J. Dairy Sci. 1998, 81, 76-81.

(26) Yang, M. C.; Guan, H. H.; Liu, M. Y.; Lin, Y. H.; Yang, J. M.; Chen, W. L.; Chen, C. J.; Mao, S. J. T. Crystal structure of a secondary vitamin D3 binding site of milk beta-lactoglobulin. Proteins: Struct., Funct., Bioinf. 2008, 71, 1197-1210.

(27) Hamdan, Y.; Pérez-Vich, B.; Fernández-Martínez, J.; Velasco, L. Inheritance of very high linoleic acid content and its relationship with nuclear male sterility in safflower. Plant Breeding 2008, 127, 507-509. 
(28) Jensen, R. G. The composition of bovine milk lipids: January 1995 to December 2000. J. Dairy Sci. 2002, 85, 295-350.

(29) Kowalski, R. Changes of linoleic acid concentration during heating of some plant-origin oils with polyphenol addition. J. Food Quality 2010, 33, 269-282.

(30) Lišková, K.; Auty, M. A. E.; Chaurin, V.; Min, S.; Mok, K. H.; O’Brien, N.; Kelly, A. L.; Brodkorb, A. Cytotoxic complexes of sodium oleate with $\beta$-lactoglobulin. Eur. J. Lipid Sci. Tech. 2011, 1207-1218.

(31) Palmquist, D. L.; Jenkins, T. C. Challenges with fats and fatty acid methods. J. Anim. Sci. 2003, 81, 3250-3254.

(32) Coakley, M.; Ross, R.; Nordgren, M.; Fitzgerald, G.; Devery, R.; Stanton, C. Conjugated linoleic acid biosynthesis by human-derived Bifidobacterium species. J. Appl. Microbiol. 2003, 94, 138-145.

(33) Qi, X.; Holt, C.; McNulty, D.; Clarke, D.; Brownlow, S.; Jones, G. Effect of temperature on the secondary structure of betalactoglobulin at $\mathrm{pH}$ 6.7, as determined by $\mathrm{CD}$ and IR spectroscopy: a test of the molten globule hypothesis. Biochem. J. 1997, 324, 341346.

(34) Seo, J. A.; He doux, A.; Guinet, Y.; Paccou, L.; Affouard, F.; Lerbret, A.; Descamps, M. Thermal denaturation of beta-lactoglobulin and stabilization mechanism by trehalose analyzed from Raman spectroscopy investigations. J. Phys. Chem. B 2010, 114, 6675-6684.

(35) Qin, B. Y.; Bewley, M. C.; Creamer, L. K.; Baker, H. M.; Baker, E. N.; Jameson, G. B. Structural basis of the Tanford transition of bovine beta-lactoglobulin. Biochemistry 1998, 37, 14014-14023.

(36) Collin, F.; Hindo, J.; Thérond, P.; Couturier, M.; Cosson, C.; Jore, D.; Gardès-Albert, M. Experimental evidence of the reciprocal oxidation of bovine serum albumin and linoleate in aqueous solution, initiated by HO-free radicals. Biochimie 2010, 92, 1130-1137.

(37) Chiyoda, C.; Peixoto, E. C. D.; Meirelles, A. J. A.; Rodrigues, C. E. C. Liquid-liquid equilibria for systems composed of refined soybean oil, free fatty acids, ethanol, and water at different temperatures. Fluid Phase Equilib. 2010, 299, 141-147.

(38) Abumrad, N.; Harmon, C.; Ibrahimi, A. Membrane transport of long-chain fatty acids: evidence for a facilitated process. J. Lipid Res. 1998, 39, 2309.

(39) Frapin, D.; Dufour, E.; Haertle, T. Probing the fatty acid binding site of beta-lactoglobulins. J. Protein Chem. 1993, 12, 443-449.

(40) Spector, A. A.; Fletcher, J. E. Binding of long chain fatty acids to beta-lactoglobulin. Lipids 1970, 5, 403-411.

(41) Loch, J.; Polit, A.; Bonarek, P.; Ries, D.; Kurpiewska, K.; Dziedzicka-Wasylewska, M.; Lewinski, K. Bovine beta-Lactoglobulin Complex with Linoleic Acid. www.rcsb.org/pdb/explore/explore. do?structureId=4DQ4; DOI: $10.2210 / \mathrm{pdb} 4 \mathrm{dq} 4 / \mathrm{pdb}$ (accessed Jun 5, 2012).

(42) Tolkach, A.; Kulozik, U. Reaction kinetic pathway of reversible and irreversible thermal denaturation of beta-lactoglobulin. Le Lait 2007, 87, 301-315.

(43) De Franceschi, G.; Frare, E.; Pivato, M.; Relini, A.; Penco, A.; Greggio, E.; Bubacco, L.; Fontana, A.; de Laureto, P. P. Structural and morphological characterization of aggregated species of $\alpha$-synuclein induced by docosahexaenoic acid. J. Biol. Chem. 2011, 286, 2226222274.

(44) Jung, J. M.; Savin, G.; Pouzot, M.; Schmitt, C.; Mezzenga, R. Structure of heat-induced beta-lactoglobulin aggregates and their complexes with sodium-dodecyl sulfate. Biomacromolecules 2008, 9, 2477-2486.

(45) Liu, X.; Shang, L.; Jiang, X.; Dong, S.; Wang, E. Conformational changes of beta-lactoglobulin induced by anionic phospholipid. Biophys. Chem. 2006, 121, 218-223.

(46) Rakib, M. A.; Kim, Y. S.; Jang, W. J.; Jang, J. S.; Kang, S. J.; Ha, Y. L. Preventive effect of t,t-conjugated linoleic acid on 12-Otetradecanoylphorbol-13-acetate-induced inhibition of gap junctional intercellular communication in human mammary epithelial MCF-10A cells. J. Agric. Food Chem. 2011, 59, 4164-4170.

(47) Kelley, N. S.; Hubbard, N. E.; Erickson, K. L. Conjugated linoleic acid isomers and cancer. J. Nutr. 2007, 137, 2599-2607.

(48) Knyazeva, E. L.; Grishchenko, V. M.; Fadeev, R. S.; Akatov, V. S.; Permyakov, S. E.; Permyakov, E. A. Who is Mr. HAMLET?
Interaction of human alpha-lactalbumin with monomeric oleic acid. Biochemistry 2008, 47, 13127-13137.

(49) Xiaofeng, L.; Haining, Y.; Qi, M.; Shengrong, S.; Undurti, D. Linoleic acid suppresses colorectal cancer cell growth by inducing oxidant stress and mitochondrial dysfunction. Lipids Health Dis. 2010, 9, 106-111.

(50) Brinkmann, C. R.; Heegaard, C. W.; Petersen, T. E.; Jensenius, J. C.; Thiel, S. The toxicity of bovine alpha-lactalbumin made lethal to tumor cells is highly dependent on oleic acid and induces killing in cancer cell lines and noncancer-derived primary cells. FEBS J. 2011, 278, 1955-1967.

(51) Beneventi, D.; Carré, B.; Gandini, A. Precipitation and solubility of calcium soaps in basic aqueous media. J. Colloid Interface Sci. 2001, 237, 142-144.

(52) Norman, A.; Bennett, L. R.; Mead, J. F.; Iwamoto, K. S. Antitumor activity of sodium linoleate. Nutr. Cancer. 1988, 11, 107115.

(53) Niot, I.; Poirier, H.; Tran, T. T. T.; Besnard, P. Intestinal absorption of long-chain fatty acids: evidence and uncertainties. Prog. Lipid Res. 2009, 48, 101-115.

(54) Stremmel, W. Uptake of fatty acids by jejunal mucosal cells is mediated by a fatty acid binding membrane protein. J. Clin. Invest. 1988, 82, 2001-2010.

(55) Marei, W. F.; Wathes, D. C.; Fouladi-Nashta, A. A. Impact of linoleic acid on bovine oocyte maturation and embryo development. Reproduction 2010, 139, 979-988.

(56) Sauer, L. A.; Dauchy, R. T.; Blask, D. E.; Krause, J. A.; Davidson, L. K.; Dauchy, E. M. Eicosapentaenoic acid suppresses cell proliferation in MCF-7 human breast cancer xenografts in nude rats via a pertussis toxin-sensitive signal transduction pathway. J. Nutr. 2005, 135, 2124-2129.

(57) Salvati, S.; Natali, F.; Attorri, L.; Raggi, C.; Biase, A. D.; Sanchez, M. Stimulation of myelin proteolipid protein gene expression by eicosapentaenoic acid in C6 glioma cells. Neurochem. Int. 2004, 44, 331-338.

(58) Ehehalt, R.; Sparla, R.; Kulaksiz, H.; Herrmann, T.; Fullekrug, J.; Stremmel, W. Uptake of long chain fatty acids is regulated by dynamic interaction of FAT/CD36 with cholesterol/sphingolipid enriched microdomains (lipid rafts). BMC Cell Biol. 2008, 9, 45. 